\section{genetically modified maize}

Canada-based Action Group on Erosion, Technology and Concentration (ETC), issued a statement alleging that "pro-industry academics are engaging in a highly unethical mud-slinging campaign against the Berkeley researchers".

The statement calls on the UN Food and Agriculture Organization and the Consultative Group on International Agricultural Research (CGIAR), which runs 16 agricultural research laboratories around the world, to "propose an immediate moratorium on the shipment of GM seed or grain in countries or regions that form part of the centre of origin or centre of genetic diversity for the species".

Alex Avery, director of research at the Virginia-based Center for Global Food Issues, which supports agricultural biotechnology, dismisses the ETC's statement as "some last-minute damage control before the Quist and Chapela study is thoroughly refuted". He claims that the ETC “doesn't care about the scientific debate - it is just trying to sway reporters into bolstering the credentials of Chapela and Quist".

Both sides of the argument are hoping to influence imminent decisions about the regulation of transgenic crops - in particular, the fate of the existing European
Union moratorium on their commercial use. The United States, which views the ban as protectionism, would like to see its removal discussed at the next meeting of European leaders in Barcelona on 15-16 March. But according to one official at the European Commission, a decision to lift the moratorium is unlikely until the end of the year at the earliest.

Some experts say that the debate on the Mexico findings is, in any case, somewhat beside the point. Because maize is windpollinated and varieties cross readily, almost everyone agrees that genes from GM maize will cross to local varieties if they are grown close together.

What really matters is the ecological impact of such gene flow. Local maize varieties are not very stable, and farmers have long crossbred them with other varieties. "Gene flow is a constant," says Tim Reeves, director of the CGIAR International Maize and Wheat Improvement Center (CIMMYT) in Mexico. "The real question is whether it makes any difference if one of the genes that flows in is a transgene."

Scientists are divided on that question. Some argue that the transgenes will reduce genetic diversity, whereas others contend that they could either have a neutral effect or actually enhance diversity.

\section{Poor nations seek new biodiversity deal}

\section{Virginia Gewin, Washington}

Twelve countries in the developing world have issued a declaration requesting an international agreement to ensure the fair and equitable sharing of benefits derived from the world's biodiversity, such as new drugs and agricultural products.

Between them, the countries - which include China, Mexico, India and Brazil claim to house nearly three-quarters of the Earth's biodiversity.

The declaration - also signed by Indonesia, Costa Rica, Colombia, Kenya, Ecuador, Peru, Venezuela and South Africa - was issued on 18 February at a meeting of environment ministers in Cancun, Mexico.

The declaration is seen as an attempt by the nations to stake out a unified position ahead of two international meetings - a conference of the parties to the Convention on Biological Diversity (CBD) in The Hague in April, and the United Nations' World Summit on Sustainable Development in Johannesburg, South Africa, in August.

The CBD was set up in 1992 to create a structure for agreement between governments and corporations for the equitable sharing of the benefits arising from biological resources. But the United States has not ratified it, and the 12 countries say that its principles are not being implemented.

\title{
Cutbacks cost jobs at agricultural institute
}

\section{K. S. Jayaraman, Hyderabad}

Lack of funds is causing severe cutbacks at one of the few agricultural institutes to focus on the needs of the world's poor.

About a quarter of the workforce at ICRISAT (the International Crops Research Institute for Semi-Arid Tropics) in Andhra Pradesh, India, will lose their jobs, as the institute attempts to make up for a shortfall in support from rich countries' governments.

The institute will undergo restructuring and define a fresh research strategy aimed at securing new sources of funding, such as foundations and corporations, said director William Dar at a press conference earlier this month. This year's budget of US\$22.3 million is down by $\$ 1.5$ million from last year. "We had no option but to streamline the functioning," Dar said. The cut in staffing the fourth in two years - will reduce numbers by 205 to 600 , the lowest since the institute was established in 1972.

Institute spokesman Murli Sharma says that failure by donors to fulfil their commitments is not new. But this year, several donor governments have backed out, using the eco-

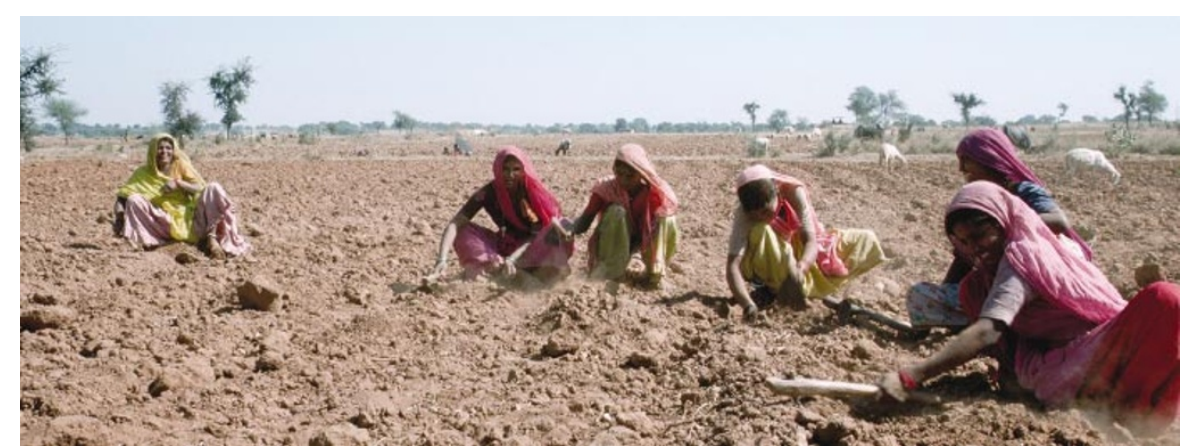

Dirt poor: women digging for groundnuts, an important crop in arid parts of India and Africa.

nomic slowdown caused by the 11 September attack on the United States as an "excuse", Sharma says. He declined to identify the defaulters.

ICRISAT is one of 16 agricultural research labs run by the Consultative Group on International Agricultural Research, based in Washington DC. Until now, its main focus has been on the five mandated crops sorghum, millet, groundnuts, chickpeas and pigeonpeas - that are important to poor farmers in arid regions of Africa and India.
Dar says the institute will now diversify into cash crops and livestock rearing, areas he hopes will attract new research sponsors.

These efforts to find new donors are starting to bear fruit. A New Delhi company, Proagro Seeds, has contributed $\$ 300,000$ for a three-year sponsored project on millet. And the Tata Trust in Mumbai has promised $\$ 1$ million for a three-year study on watershed management. "We need more nontraditional donors," Dar says.

www.icrisat.org 